\title{
Cowboys, cancer, kids, and cash flow: the 1992 Philip Morris annual meeting
}

\author{
Alan Blum
}

To listen to the fiery health advocate Dr Greg Connolly berating executives of the world's largest and most profitable tobacco company barely two weeks after I had participated in the eighth world conference on tobacco or health is to appreciate Henry David Thoreau's remark, "There are a thousand hacking at the branches of evil to one who is striking at the root." A decade ago I purchased shares in each of the American tobacco companies in order to receive their annual reports and other mailings, and for four of the past five years I have found myself in Richmond, Virginia, on a Thursday late in April sitting side by side with some of America's wealthiest and most bronchitic businessmen and women.

The first year I went alone - my Richmond host was too frightened to enter the enormous cigarette factory-and I myself felt like a yeshiva student at a skinhead rally. In the midst of glowing reports of burgeoning global cigarette sales one executive received a standing ovation for having introduced Marlboro to 13 new countries during the previous year. Intimidated by the affair, I asked someone I took to be in public relations if I could snap a few photographs. He laughingly informed me he was the business writer for the Richmond Times-Dispatch, who after ascertaining that I was a legitimate would-be fly in the ointment, wound up writing his article about the unnoticed medical activist in the audience who was launching a strategy to scrutinise company officials and to infiltrate the annual meeting.

Each year following the meeting I would go on tours of the building in electric carts emblazoned with Marlboro. The patter was delivered by college age women with winning smiles and sparkling teeth. None smoked. The spotless factory floor seemed the size of several football fields. Most employees wore starched white laboratory coats while tending the high speed machines. At the gift shop I purchased numerous items imprinted with the company's cigarette brand names: T-shirts, shorts, umbrellas, jewellery, playing cards - even a Marlboro first aid kit. When I asked a cashier in the company cafeteria the location of the no smoking section, I thought she would die of disbelief.

Doctors Ought to

Care (DOC),

Department of

Family Medicine,

Baylor College of

Medicine, 5510

Greenbriar, Houston,

Texas 77005, USA

A Blum

\section{Proud shareholders}

By $1991 \mathrm{my}$ role had evolved to become part of a small supporting cast of individuals who stand up to speak on behalf of shareholders' resolutions calling for the end to tobacco promotion to young people in the United States and around the world. The leader of the group was Father Michael Crosby, whose religious order, the Midwest Province of the Capuchin Franciscan order, invests in stocks to earn income for its work among the poor. To those who believe in the effectiveness of warning labels, Father Crosby's efforts paid off when Philip Morris announced early this year that it would begin placing the US Surgeon General's health warning on all of its cigarette packages worldwide. From the company's perspective this met one of the major concerns of opponents of cigarette marketing in poor nations and avoided another shareholder proposal. Indeed, Father Crosby withdrew his latest resolution on marketing to the Third World and in a statement read by a colleague at this year's meeting thanked the company for its responsiveness. This was sadly reminiscent of the testimonial at the 1991 meeting by a member of the AIDS activist group ACT-UP, which dropped its boycott of Philip Morris begun because of the company's political and financial support of the militantly homophobic US senator Jesse Helms - after the company agreed to give $\$ 1$ million for AIDS research.

The annual meeting of Philip Morris is a festive occasion for senior executives and shareholders alike, who look like wedding guests as they arrive to sign in under a huge tent on the front lawn. This year most chose to wear a bright orange company sticker that reads, "I'm proud to be a Philip Morris shareholder." After snacking on Kraft juices, Entenmanns pastries, and Maxwell House coffee - all Philip Morris products acquired in the hostile takeovers of General Foods and Kraft in the mid-1980s - the well dressed crowd of 600 , comprising the holders of $84 \%$ of the company's common stock, was ushered into the building and downstairs to an intimate, softly lit auditorium. This is one meeting at which smoking is most assuredly permitted and constant coughing most definitely ignored.

A five minute video montage of old television commercials for dozens of the company's 3000 food and tobacco products was repeated three times, interspersed with the commanding voice of actor James Earl Jones, who intones, "Consumers choose our brands with confidence." Against images of Marlboro Indy race cars, Marlboro cowboys and horses, Virginia Slims cigarette packs, and Virginia Slims teenage tennis players, the actor boasts that such advertising "rises above barriers of 
language and geography-dynamic brands generating unforgettable excitement."

The meeting was called to order by the chairman of the board and chief executive officer Michael A Miles, aged 52, who is also a member of the executive, finance, and public affairs and social responsibility committees. The term "social responsibility" is frequently invoked by Philip Morris executives and writers of the company's annual report. One member of the board of directors, Citibank chairman John S Reed, serves on the board of New York's prestigious Memorial SloanKettering Cancer Center. Another director, Chicago attorney John M Richman, sits on the board of Evanston Hospital (just north of Chicago). The two women directors, Professor Elizabeth E Bailey of the University of Pennsylvania and business leader Jane Evans, sit on the social responsibility committee. Other directors include international newspaper, television, publishing, and communications boss Rupert Murdoch; Marlboro Indy racing team owner Roger Penske; and New York Stock Exchange chairman William Donaldson.

After the election of directors and the selection of auditors, this year's two stockholder proposals were presented and discussed. Citing various condemnations of Philip Morris' Miller Brewing Company subsidiary for advertising that appeals to adolescents, $\mathrm{Dr}$ John Slade, a well known addiction medicine specialist, asked the management to prepare a report to the board discussing the degree to which, even if unintentional, the company's marketing on television, on college campuses, and through sports sponsorship affects teenagers.

\section{Image and reality}

This year's tobacco related resolution was then brought forward by Dr Connolly, director of the Massachusetts Office for Nonsmoking and Health, who called upon the company to adhere to its own voluntary code of cigarette advertising in which it promises to avoid directly or indirectly appealing to youth such as by the use of athletes, singers, or other celebrities to which teenagers are attracted. His prepared statement noted that if current smoking patterns continue, approximately five million US children alive today will die from smoking. Connolly said he was directing his comments not at Philip Morris executives but rather at representatives of institutional investors - the retirement funds whose "pensioners want to see their grandchildren graduate from medical school and the insurance companies who want to see smoking reduced so that health costs will go down." $\mathrm{He}$ punctuated his impassioned speech by citing blatant violations of the code and by holding up disquieting examples of Virginia Slims cigarette advertisements with youthful models.

Dr Connolly's proposal for a company sponsored study of the impact of cigarette advertising on young people was seconded by Wayne McLaren, an actor, stuntman, and model in advertisements for cigarettes, in-

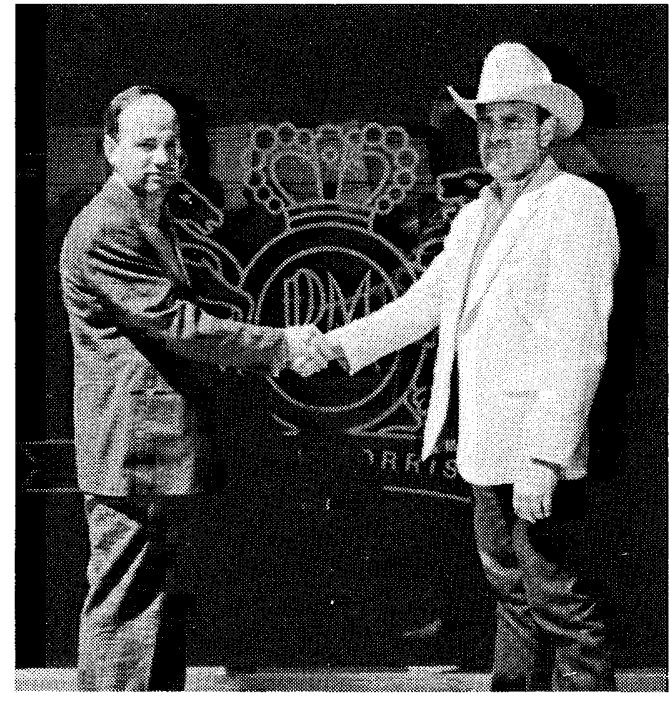

Dr Greg Connolly with Wayne McLaren, a former Marlboro model and current lung cancer victim, at the 1992 Philip Morris annual meeting

cluding Marlboro. Wearing a white cowboy hat, white sports coat, and jeans, he recalled that those he has worked with over 20 years who produce cigarette advertisements for the print media were no less confident of their power to influence the public than their peers in film and television production were of theirs. $\mathrm{He}$ added that recently, after having smoked for 30 years, he was diagnosed as having inoperable lung cancer. "I do believe I have perhaps a better handle on cigarette smoking and advertising than most people," he concluded to a hushed audience. Dr Slade then commented that, by his calculation, Philip Morris' profits on cigarette sales to minors in 1991 totalled $\$ 190$ million, an amount he felt the company should devote to mass media campaigns to discourage smoking.

The resolutions require approval by at least $3 \%$ of the shareholders present to be brought forward for automatic reconsideration the following year, then $5 \%$ for the year after that. The tobacco proposal received $6.58 \%$ of votes cast, and thus the subject may well be raised again in 1993. But when one considers the five million shares owned by the executives and board members themselves, it becomes absurd to think that Philip Morris will do anything to jeopardise its main source of profit. Indeed, as Philip Morris chairman Miles stated at this year's meeting, "We cannot and will not take any action that will diminish our viability in each of the company's three major sectors: tobacco, beer, and food." On the other hand, as Connolly points out, there are many large institutional and corporate shareholders of tobacco stocks - such as the insurance industry - who would doubtless not relish the negative publicity of appearing to be hypocritical either by investing in tobacco or in voting with management. Father Crosby notes that the five top US insurance companies each held thousands of shares of tobacco stocks and did not support his 1982 shareholders' resolution which called for a review of cigarette marketing practices in the Third World. At the time any 
shareholder protesting such policies of tobacco companies was the voice of one crying in the wilderness. But as with the apartheid issue, major shareholders of Philip Morris may prove to be the ones to reduce the company's dependence on tobacco.

For now, though, any hope that Philip Morris on its own will gradually shift its emphasis away from tobacco and into food - a common rationalisation on the part of individuals in universities and pension funds who defend their purchase of shares in the company - is a delusion. "Our historic success as a tobacco company will be a hard act to follow," teased chairman Miles, all but admitting that there won't be any new act at all.

Company president Bill Murray supplied the argument for standing firm in tobacco: "Income of our domestic cigarette business increased $14 \%$ and revenues were up $12 \%$, so that our company now has $43.3 \%$ of the total US cigarette market." (RJ Reynolds is second at $29 \%$.) Like a proud papa, Murray noted that Marlboro, 344 billion units of which were sold worldwide in 1990, now accounts for $26 \%$ of US cigarette sales and that "we are further building the Marlboro family." To one who is a family doctor, this use of the word "family" by a cigarette pusher convinced me I had entered the world of anti-matter. This impression was reinforced by Murray's concluding comments on the US cigarette business about the future of tobacco product liability lawsuits, the most famous of which-the Cipollone case - was awaiting a ruling from the Supreme Court. "Whatever the Court should decide [that is, whether federally mandated warning labels preempt such suits], we think the litigation issue will remain manageable," he said. "Juries will continue to find in favour of cigarette companies, understanding that people who smoke are aware of the claimed health risks."

\section{Lite 'n' deadly}

The president's presentation of the food products sales picture was more vague, less glowing: "We solidified our leadership in frozen bagels," "expanded our ready to drink juice portfolio," and "maintained the leading share of the turkey bacon category." Turkey bacon is no laughing matter to a company that, according to the annual report, recognises that "lower fat and cholesterol now head the list of consumers' dietary concerns." A pioneer in what it calls "fat replacement technology," Philip Morris produces non-fat salad dressings, low fat cheeses, and cholesterol-free mayonnaise. The operative word is "light." Amid a host of items such as Kraft Light Singles cheese, Cool Whip Lite dessert topping, Light n' Lively yoghurt, and Lite beer, products such as Marlboro Lights and Virginia Slims Lights appear to fit nicely into the company's emphasis on health. Indeed, the word "synergy" is used so often in the annual report to describe the company's integrated marketing programmes for different products that one might expect the announcement of a nicotine flavoured dessert topping or a tobacco based breakfast cereal. The bottom line is that in spite of the fact that most of the company's 3000 products are food related, food contributes only $30 \%$ of the company's profits; tobacco, well over $60 \%$. Put another way, one brand of cigarettes - Marlboro - accounts for far greater profit than all of Kraft General Foods combined! (Less than two weeks after the annual meeting, Philip Morris announced the elimination of 1000 employees of Kraft General Foods in the United States $-5 \%$ of the division's salaried workers.)

As it was difficult to put a gloss on the flat domestic food business, the president's presentation shifted to the increasingly profitable international tobacco divisions: "Last year our cigarette volume in Latin America increased by $9 \%$ as we built on the success of our brands... With a strong base in Europe, newly accessible markets in Eastern Europe, and the rapidly expanding Asian market, we are poised to enter a new period of profitable and sustainable growth." Hungary, Russia, Czechoslovakia, and other Eastern European countries have all been rounded up for Marlboro.

A recitation by chief financial officer Hans Storr of dramatic increases in net earnings and earnings per share - in the first quarter of 1992 net earnings increased by $100 \%$ to $\$ 1.1$ billion - culminated in the excited prediction that "from 1992 through the end of 1996 we expect our operations to generate at least $\$ 21$ billion in free cash flow" after capital expenses and dividends.

Not overlooked was Philip Morris's salute to its corporate citizenship. The "who's who" of company hand outs includes the United Negro College Fund, the National Urban League, the National Black and Minority Chamber of Commerce, the National Hispanic Scholarship Fund, the National Women's Political Caucus, and assorted museums, dance troupes, and universities. Not the least self interested initiative was a grant to a group called the Food Research and Action Center to explore the impact of poor nutrition on education. The annual report modestly notes, "We are the leading underwriter of the national campaign to end childhood hunger."

\section{Life sentence?}

In the brief general discussion period a representative from the National Family Farm Coalition accused Philip Morris of controlling cheese prices and helping to drive dairy farmers out of business. I had an opportunity to ask about a previously unrevealed criminal investigation of Philip Morris and other tobacco companies by the same US attorney's office that successfully prosecuted New York mob boss John Gotti. Professor Richard Daynard of the Tobacco Product Liability Project had informed me that the government is exploring a possible conspiracy between Philip Morris and other tobacco companies in the industry's Council for Tobacco Research to subvert scientific research that reported on the deleterious effects of smoking. "Mr Chairman," I asked, "what effect would a criminal 
conviction or the seizure of our company's assets under the RICO (Racketeer Influenced and Corrupt Organisations) statute have on the company?" "A speculative question. Pure speculation," Miles replied.

No Philip Morris annual meeting would be complete without an unrehearsed testimonial from a member of the audience - in this instance a grandmotherly New Jersey real estate agent - in praise of $\mathrm{Mr}$ Miles, the beautiful day, and Southern hospitality. The loud, tension breaking applause she received rivalled the standing ovation given earlier in the meeting to immediate past chairman Hamish Maxwell, under whose eight year reign the value of the company's stock multiplied nearly eightfold. (Dr Connolly had noted in his statement that the $\$ 46$ million bonus Maxwell received on stepping down was more than the entire income of all of Virginia's tobacco farmers and more than the annual amount of tobacco taxes the state takes in.)
As the audience filed out, each person (except for the grandchildren of some of the board members) received a gift box of Philip Morris products, including two packets of cigarettes, two packets of coffee, two chocolate bars, a box of macaroni and cheese, a packet of Jell-o, and a shopping list with all of the company's brand names. Outside, local television stations, alerted to the presence of a former Marlboro man, crowded around him for interviews. Nearby, Philip Morris vice president for minority affairs George Knox was also interviewed by a television reporter. He claimed the company has no record that McLaren ever appeared in its advertisements and implied it was all a hoax. Some of the reporters believed that McLaren's cheque stubs for Marlboro modelling payments and chest $x$ rays for lung cancer spoke for themselves. The reporters seemed familiar with the other things over the years that Philip Morris had been saying just weren't so. 